specialist, and each author's personal experience of his subject explains the lively approach of the work. All annoying heterogeneity has been completely smoothed out by the three editors : Dr. H. Rooksby, on techniques; Dr. A. J. C. Wilson, on methods of interpretation; and Dr. H. S. Peiser, on applications. All the authors are British, and to me as a Frenchman this shows how numerous in Britain is the school of $\mathrm{X}$-ray crystallographers continuing brilliantly the work of their teachers who founded this science.

A. GUINIER

\section{ERASMUS DARWIN}

The Temple of Nature; or, the Origin of Society A Poem, with Philosophical Notes. By Erasmus Darwin. (In Russian.) Pp. $239+6$ plates. (Moskva : Izdatelstvo Akademii Nauk SSSR., 1954.) 12 roubles, 80 kopecks.

T' may be that the great admiration felt for Charles Darwin in the U.S.S.R. induced the Academy of Sciences to re-publish the Russian translation of this poem of his grandfather. "The Temple of Nature", by Erasmus Darwin, was originally published in 1803, a year after his death. The original Russian translation of this poem was published in 1911 in the Journal of the Ministry of Education in St. Petersburg. The translator, N. A. Kholodkovsky (1858-1921), was rather a remarkable man-a professor of zoology, a poet and a gifted translator of Milton, Shakespeare, Byron and Goothe.

"The Temple of Nature" is probably less known than "The Botanic Garden" by the same author. It is a didactic-scientific poem written in pseudoclassical style in heroic couplets. It is not a major poetic work, but it is not without certain charm and is full of humour, much of it clearly unconscious. Here is a fragment of it, chosen at random :

"In earth, sea, air, around, below, above,

Life's subtle woof in Nature's loom is wove;

Points glued to points a living line extends,

Touch'd by some goad approach the bending ends ;

Rings join to rings, and irritated tubes

Clasp with young lips the nutrient globes or cubes;

And urged by appetencies new select,

Imbibe, retain, digest, secrete, eject."

The translator really did a wonderful job not only in bringing out the full meaning of the poem but also in preserving the style, rhyming sequence and metre of the original. To do this he had to expand the original 1,928 lines into 2,247 lines.

In addition to the full text of the poem, the volume contains Charles Darwin's life of his grandfather in translation, two sets of notes by Erasmus Darwin, also in translation, one set by the translator and one set by the editor, who also provides a biographical sketch of the translator. There are two portraits of Erasmus Darwin, one of the translator and other illustrations.

The book is carefully edited by E. N. Pavlovsky, director of the Zoological Institute of the Academy of Sciences in Leningrad, a significant fact especially when it is realized that the translator, N. A. Kholodkovsky, was also a prominent zoologist.

The poem is an expression of Darwin's scientific views on the origin and development of life, the evolution of the mind and the growth of society. Like his "Botanic Garden", this poem is an invaluable record of scientific thought at the end of the eighteenth century. The publication of the Russian translation of this is not intended as a homage to a minor English poet, but as an important contribution to the evergrowing Russian literature relating to the history of science.

S. I. TOMKEIEYF

\section{SYSTEMATIC ZOOLOGY}

Methods and Principles of Systematic Zoology

By Ernst Mayr, Prof. E. Gorton Linsley, and Prof. Robert L. Usinger. (McGraw-Hill Publications in the Zoological Sciences.) Pp. ix +328 . (London : McGraw-Hill Publishing Co., Ltd., 1953.) $51 s$.

TOVELTY usually brings rapid developments in a science followed by a spate, sometimes superabundant, of text-books and treatises. The novelty of the new systematics is, however, unspectacular either in methods or results, and development in taxonomy has been correspondingly slow, with the need for a comprehensive treatise growing equally slowly. The need has, however, been very acute for many years, and zoologists can count themselves fortunate that it has now been satisfied in proportion to its intensity. The three authors have brought to the task not merely the essential knowledge but also breadth of understanding and an ability for lucid and logical exposition.

The book, "a concise presentation of the methods and principles of zoological classification", is subdivided into three parts, of which the first, and shortest, deals with the history of taxonomy and proceeds logically to consider changed concepts and the status of the hierarchical categories. Part 2, taxonomic procedure, is a step-by-step guide from advice on the selection of the problem and assembling the pertinent material and information, to the preparation of the paper describing the results, selecting its title and seeing it through the press. Much of this part is, of course, elementary; but much that is complex is made to seem elementary, not by over-simplification but by clear thinking and presentation. The phenomena the taxonomist will, or may, encounter and the methods he will, or ought to, use for dealing with them are themselves treated in taxonomic fashion and grouped in logical categories. It is a sorry comment on human frailty that nomenclature, which should be merely the handmaiden of zoologists, has so beguiled some and bedevilled others that the section dealing with it needs the equivalent of a quarter of the whole book. But that is not the fault of the book, nor of its authors, and students will find the section very useful even though the important Copenhagen Decisions (1953) were not available in time for inclusion.

"Methods and Principles" is an essential text. book for all students of evolution and taxonomy and a valuable reference book for practising systematists however experienced they may be. Much of it should be read by any zoologist who would claim to have a broad and liberal understanding of his subject. There are, naturally, some expressions of opinion that are controversial, but errors are notably few and generally insignificant. The authors will therefore find it especially galling that the statistical section, which the non-mathematically minded may follow blindly, contains a slip; the numerical value of the standard error of the difference between means (p. 142) is not an index of significance.

H. W. Parker 